\title{
REALISTIC MATHEMATICS EDUCATION: MODEL ALTERNATIF PEMBELAJARAN MATEMATIKA SEKOLAH
}

\author{
Seri Ningsih
}

\begin{abstract}
Abstrak
Matematika yang diajarkan pada jenjang pendidikan dasar (SD dan SMP) dan pendidikan menengah (SMU dan SMK) dikenal sebagai matematika sekolah (School Mathematics). Matematika sekolah adalah bagian-bagian matematika yang dipilih atas dasar makna kependidikan yaitu untuk mengembangkan kemampuan dan kepribadian siswa serta tuntunan perkembangan yang nyata dari lingkungan hidup yang senantiasa berkembang seiring dengan kemajuan ilmu dan teknologi. Matematika sekolah dapat diaplikasikan dalam pembelajaran matematika melalui berbagai model pembelajaran. Pembelajaran Matematika Realistik (PMR) atau Realistic Mathematics Education (RME) adalah model pembelajaran matematika pada matematika sekolah yang berorientasi pada penerapan matematika dalam kehidupan sehari-hari.
\end{abstract}

Kata Kunci : Matematika Sekolah, Realistic Mathematics Education, Pembelajaran

\section{A. Pendahuluan}

Matematika sebagai salah satu ilmu dasar, baik dalam aspek terapan maupun aspek penalaran, mempunyai peranan yang penting dalam upaya penguasaan ilmu dan teknologi. Indikasi pentingnya matematika dapat dilihat dari pembelajaran matematika sebagai salah satu mata pelajaran yang diberikan di setiap jenjang pendidikan. Matematika yang diajarkan pada jenjang pendidikan dasar (SD dan SMP) dan pendidikan menengah (SMU dan SMK) dikenal sebagai matematika sekolah (School Mathematics). Matematika sekolah adalah bagian-bagian matematika yang dipilih atas dasar makna kependidikan yaitu untuk mengembangkan 
kemampuan dan kepribadian siswa serta tuntunan perkembangan yang nyata dari lingkungan hidup yang senantiasa berkembang seiring dengan kemajuan ilmu dan teknologi.

Kenyataannya sampai saat ini matematika masih menjadi masalah bagi sebagian siswa. Hal ini memberikan kesan bahwa kualitas pendidikan matematika yang ada masih jauh dari harapan. Fakta menyatakan berdasarkan kajian Programme for International Student Asssessment (PISA) 2003, Sutarto Hadi dalam majalah PMRI (2007:3) mengemukakan sebanyak 50,5\% siswa Indonesia memiliki kemampuan keberaksaraan matematika di bawah level 1, yaitu hanya mampu menyelesaikan satu langkah soal matematika (pada situasi ini siswa bahkan tidak dapat menggunakan prosedur, rumus, dan algoritma sederhana untuk menyelesaikan soal matematika). Sebanyak $27,6 \%$ berada pada level 1 , yaitu dapat menggunakan prosedur, rumus, dan alagoritma dasar, serta mampu melakukan penafsiran yang bersifat aksara dan penalaran yang bersifat langsung. Sebanyak $14,8 \%$ berada pada level 2, yaitu mampu menerapkan pemecahan masalah sederhana, menafsirkan dan menyampaikannya. Sebanyak $5,5 \%$ berada pada level 3, yaitu siswa dapat menyelesaikan persoalan secara efektif untuk situasi konkret dan dapat menyampaikan penjelasan dan argumentasi dengan baik. Hanya 1,4\% berada pada level selanjutnya.

Kualitas pendidikan matematika yang masih jauh dari harapan tersebut ternyata dibarengi dengan aktivitas siswa yang kurang terlibat aktif dalam proses pembelajaran matematika. Pada tahap pengembangan kegiatan inti pembelajaran, ketika penyajian konsep dan demonstrasi keterampilan matematis melalui pembahasan contoh soal, hanya segelintir siswa saja yang dapat diajak berkomunikasi, dalam arti dapat menjawab pertanyaan atau mengajukan pertanyaan. Sebagian besar siswa takut mengemukakan pendapat atau gagasan di hadapan guru, padahal guru sudah membuka kesempatan untuk bertanya, menjawab atau memberi tanggapan atas penjelasan yang sudah disampaikan. Dengan kata lain, 
Realistic Mathematics Education : Model Alternatif Pembelajaran Matematika Sekolah

antara guru dan siswa seolah-olah terdapat hambatan psikologis yang menghalangi siswa untuk belajar secara aktif. Selanjutnya pada tahap penerapan, ketika tiba saatnya untuk menggunakan konsep, aturan dan rumus dalam menyelesaikan soal, banyak siswa yang hanya menyontek pekerjaan temannya tanpa mau berpikir sedikitpun atau menanyakan bagaimana proses memperoleh jawaban penyelesaian soal. Demikian pula saat ulangan atau ujian, siswa tampak kurang percaya pada kemampuannya sendiri dalam menyelesaikan soal. Bila didasarkan data tersebut dapat disimpulkan bahwa prestasi dan aktivitas belajar matematika anak Indonesia masih sangat rendah.

Sejalan dengan paradigma baru pendidikan di Indonesia yang lebih menekankan pada siswa sebagai manusia yang memiliki potensi untuk belajar dan berkembang, pemerintah mendorong pelaksanaan pembelajaran pada jenjang pendidikan dasar dan pendidikan menengah yang berorientasi pada pembelajaran yang dirancang agar mengaktifkan anak mengembangkan kreatifitas sehingga efektif dan menyenangkan. Pembelajaran matematika sekolah bertujuan mengkonstruksi pengetahuan dari konteks benda-benda konkrit sebagai titik awal bagi siswa guna memperoleh konsep matematika. Benda-benda konkret dan objek-objek lingkungan sekitar dapat digunakan sebagai konteks pembelajaran matematika dalam membangun keterkaitan matematika melalui interaksi sosial. Benda-benda konkret dimanipulasi oleh siswa dalam kerangka menunjang usaha siswa dalam proses matematisasi konkret ke abstrak. Siswa perlu diberi kesempatan agar dapat mengkontruksi dan menghasilkan matematika dengan cara dan bahasa mereka sendiri melalui guru sebagai mediator pembelajaran. Optimalisasi pengetahuan siswa dari objek lingkungan sekitar memunculkan adanya pembelajaran matematika yang bersifat nyata yang disebut Realistic Mathematics Education. Realistic Mathematics Education di Indonesia lebih dikenal sebagai Pendekatan Matematika Realistik merupakan suatu pendekatan yang bertujuan 
Seri Ningsih

memotivasi siswa untuk memahami konsep matematika dengan mengaitkan konsep tersebut dengan permasalahan dalam kehidupan sehari-hari. Oleh karena itu, permasalahan yang digunakan dalam pembelajaran dengan Pendekatan Matematika Realistik harus mempunyai keterkaitan dengan situasi nyata yang mudah dipahami dan dibayangkan oleh siswa sehingga dapat meningkatkan struktur pemahaman matematika siswa.

\section{B. Realistic Mathematic Education pada Pembelajaran Matematika Sekolah}

\section{Hakekat Realistic Mathematics Education (RME)}

Realistic Mathematics Education (RME) atau Pembelajaran Matematika Realistik (PMR) merupakan teori belajar mengajar dalam pendidikan matematika. Teori RME pertama kali diperkenalkan dan dikembangkan di Belanda pada tahun 1970 oleh institute Freudenthal. RME telah dikembngkan dan diujicobakan selama 33 tahun di Belanda dn terbukti berhasil merangsang penalaran dan kegiatan berpikir siswa (dalam Hobri, 2009: 160). Teori ini mengacu kepada pendapat Freudental (dalam Hobri: 164) yang mengatakan bahwa matematika harus dikaitkan dengan realita dan matematika merupakan aktivitas manusia. Ini berarti matematika harus dekat dengan anak dan relevan dengan kehidupan nyata sehari-hari. Gravemeijer (dalam Zainurie : 1) mengemukakan bahwa matematika sebagai aktvitas manusia berarti manusia harus diberikan kesempatan untuk menemukan kembali ide dan konsep matematika dengan bimbingan orang dewasa. Upaya ini dilakukan melalui penjelajahan berbagai situasi dan persoalan-persoalan "realistik". Realistik dalam hal ini dimaksudkan tidak mengacu pada realitas tetapi pada sesuatu yang dapat dibayangkan oleh siswa diungkapkan oleh Slettenhar (dalam Zaenurie: 1). Prinsip penemuan kembali dapat diinspirasi oleh prosedur-prosedur pemecahan informal, sedangkan proses penemuan kembali menggunakan konsep matematisasi. 
Realistic Mathematics Education : Model Alternatif Pembelajaran Matematika Sekolah

Dua jenis matematisasi diformulasikan oleh Treffers(dalam Zainurie: 2), yaitu matematisasi horizontal dan vertikal. Contoh matematisasi horizontal adalah pengidentifikasian, perumusan, dan penvisualisasi masalah dalam cara-cara yang berbeda, dan pentranformasian masalah dunia real ke masalah matematik. Contoh matematisasi vertikal adalah representasi hubungan-hubungan dalam rumus, perbaikan dan penyesuain model matematik, penggunaan model-model yang berbeda, dan penggeneralisasian. Kedua jenis matematisasi ini mendapat perhatian seimbang, karena kedua matematisasi ini mempunyai nilai sama.

De Lange (dalam Hobri: 161) membedakan empat pendekatan dalam pendidikan matematika berdasarkan komponen matematisasinya. Pendekatan matematika berdasarkan komponen matematisasi horizontal dan matematisasi vertikal yaitu mekanistik, empiristik, strukturalistik dan realistik.

Perbedaan keempat pendekatan dalam pendidikan matematika ditekankan sejauh mana pendekatan tersebut memuat atau menggunakan kedua komponen tersebut.

1. Pendekatan mekanistik merupakan pendekatan tradisional dan didasarkan pada apa yang diketahui dari pengalaman sendiri (diawali dari yang sederhana ke yang lebih kompleks). Dalam pendekatan ini manusia dianggap sebagai mesin. Kedua jenis matematisasi tidak digunakan.

2. Pendekatan emperistik adalah suatu pendekatan dimana konsepkonsep matematika tidak diajarkan, dan diharapkan siswa dapat menemukan melalui matematisasi horizontal.

3. Pendekatan strukturalistik merupakan pendekatan yang menggunakan sistem formal, misalnya pengajaran penjumlahan cara panjang perlu didahului dengan nilai tempat, sehingga suatu konsep dicapai melalui matematisasi vertikal. 
Seri Ningsih

4. Pendekatan realistik adalah suatu pendekatan yang menggunakan masalah realistik sebagai pangkal tolak pembelajaran. Melalui aktivitas matematisasi horizontal dan vertikal diharapkan siswa dapat menemukan dan mengkonstruksi konsep-konsep matematika.

\section{Prinsip dan Karakteristik Pembelajaran Matematika Realistik}

Gravemeijer (dalam Hobri: 166) mengemukakan tiga prinsip kunci PMR, yaitu:

1. Penemuan kembali secara terbimbing melalui matematisasi progresif (Guided Reinvention Through Progressive Mathematizing). Menurut prinsip “Guided Reinvention", siswa harus diberi kesempatan mengalami proses yang sama dengan proses yang dilalui para ahli ketika konsep-konsep matematika ditemukan.

2. Fenomena didaktik (Didactical Phenomenology). Menurut prinsip fenomena didaktik, situasi yang mejadi topik matematika diaplikasikan untuk diselidiki berdasarkan dua alasan; (1). Memunculkan ragam aplikasi yang harus diantisipasi dalam pembelajaran, dan (2). Mempertimbangkan kesesuaian situasi dari topik sebagai hal yang berpengaruh untuk proses pembelajaran yang bergerak dari masalah nyata ke matematika formal.

3. Pengembangan model mandiri (self developed models). Model matematika dimunculkan dan dikembangkan sendiri oleh siswa berfungsi menjembatani kesenjangan pengetahuan informal dan matematika formal, yang berasal dari pengetahuan yang telah dimiliki siswa.

Menurut Hobri (2009: 168-170) ketiga prinsip tersebut dioperasionalkan ke dalam karakteristik PMR sebagai berikut:

1. Menggunakan masalah kontekstual (the use of contex).

Pembelajaran dimulai dengan menggunakan masalah kontekstual sebagai titik tolak atau titik awal untuk belajar. Masalah kontekstual 
Realistic Mathematics Education : Model Alternatif Pembelajaran Matematika Sekolah

yang menjadi topik pembelajaran harus merupakan masalah sederhana yang dikenali siswa.

2. Menggunakan model (use models, bridging by verti instruments). Model disini sebagai suatu jembatan antara real dan abstrak yang membantu siswa belajar matematika pada level abstraksi yang berbeda. Istilah model berkaitan dengan model situasi dan model matematik yang dikembangkan oleh siswa sendiri (self develop models). Peran self develop models merupakan jembatan bagi siswa dari situasi real ke situasi abstrak atau dari matematika informal ke matematika formal. Artinya siswa membuat model sendiri dalam menyelesaikan masalah. Pertama model situasi yang dekat dengan dunia nyata siswa. Generalisasi dari formalisasi model tersebut akan berubah menjadi model-of masalah tersebut. Melalui penalaran matematik model-of akan bergeser menjadi model-for masalah yang sejenis. Pada akhirnya, akan menjadi model matematika formal.

3. Menggunakan kontribusi siswa (student contribution). Kontribusi yang besar pada proses belajar mengajar diharapkan datangnya dari siswa. Hal ini berarti semua pikiran (konstruksi dan produksi) siswa diperhatikan.

4. Interaktivits (interactivity). Interaksi antarsiswa dengan guru merupakan hal yang mendasar dalam PMR. Secara eksplisit bentukbentuk interaksi yang berupa negosiasi, penjelasan, pembenaran, setuju, tidak setuju, pertanyaan atau refleksi digunakan untuk mencapai bentuk formal dari bentuk-bentuk informal siswa.

5. Terintegrasi dengan topik lainnya (intertwining). Dalam PMR pengintegrasian unit-unit matematika adalah esensial. Jika dalam pembelajaran kita mengabaikan keterkaitan dengan bidang yang lain, maka akan berpengaruh pada pemecahan masalah. Dalam mengaplikasikan matematika, biasanya diperlukan pengetahuan yang lebih kompleks. 
Sedangkan Prinsip-prinsip pokok pembelajaran matematika secara PMR yang dikemukakan oleh Marpaung (2003: 5-6) yaitu :

1. Prinsip Aktivitas. Prinsip ini menyatakan bahwa matematika adalah aktivitas manusia. Matematika paling baik dipelajari dengan melakukannya sendiri.

2. Prinsip Realitas. Prinsip ini menyatakan bahwa pembelajaran matematika dimulai dari masalah-masalah dunia nyata yang dekat dengan pengalaman siswa (masalah yang realistis bagi siswa). (Catatan : realistis bagi siswa diartikan tidak selalu berkaitan dengan dunia nyata, bisa juga dari dunia lain tetapi dapat dibayangkan oleh siswa). Jika matematika diajarkan lepas dari pengalaman siswa maka matematika itu mudah dilupakan.

3. Prinsip Penjenjangan. Prinsip ini menyatakan bahwa pemahaman siswa terhadap matematika melalui berbagai jenjang yaitu dari menemukan (to invent) penyelesaian kontekstual secara informal ke skematisasi. Kemudian perolehan insight dan penyelesaian secara formal.

4. Prinsip Jalinan. Prinsip ini menyatakan bahwa materi matematika di sekolah tidak di pecah-pecah menjadi aspek-aspek (learning strands) yang diajarkan terpisah-pisah.

5. Prinsip Interaksi. Prinsip ini menyatakan bahwa belajar matematika dapat dipandang sebagai aktivitas sosial selain sebagai aktivitas individu. (Prinsip ini sesuai dengan pandangan filsafat konstruktivisme, yaitu bahwa di satu pihak pengetahuan itu adalah konstruksi sosial (Vijgotskij) dan di lain pihak sebagai konstruksi individu (Piaget)).

6. Prinsip Bimbingan. Prinsip ini menyatakan bahwa dalam menemukan kembali (reinvent) matematika, siswa perlu mendapat bimbingan. 
Realistic Mathematics Education : Model Alternatif Pembelajaran Matematika Sekolah

Karakteristik PMR di atas diungkapkan pula oleh Marpaung (2003: 6) yaitu:

1. Siswa aktif, guru aktif $\rightarrow$ matematika sebagai aktivitas manusia.

2. Memulai dengan masalah kontekstual/realistik $\rightarrow$ Masalah Realistik artinya dapat dibayangkan oleh siswa atau berasal dari masalahmasalah dalam dunia nyata.

3. Memberikan kesempatan kepada siswa untuk menyelesaikan masalah dengan cara sendiri-sendiri $\rightarrow$ Lintasan belajar siswa.

4. Menciptakan suasana pembelajaran yang menyenangkan $\rightarrow$ Kondisi belajar.

5. Siswa dapat menyelesaikan masalah secara individu atau dalam kelompok (kecil atau besar) $\rightarrow$ (diskusi, interaksi, negosiasi).

6. Pembelajaran tidak selalu di kelas (bisa di luar kelas, duduk di lantai, pergi ke luar sekolah untuk mengamati atau mengumpulkan data) $\rightarrow$ Variasi Pembelajaran.

7. Guru memberikan kesempatan kepada siswa untuk merenungkan proses atau makna $\rightarrow$ Refleksi.

8. Siswa bebas memilih modus representasi yang sesuai dengan struktur kognitifnya sewaktu menyelesaikan suatu masalah (penggunaan model) $\rightarrow$ Translasi modus representasi atau model.

9. Guru bertindak sebagai fasilitator $\rightarrow$ Tutwuri Handayani.

10. Kalau siswa membuat kesalahan dalam menyelesaikan masalah, jangan dimarahi tetapi dihargai dan dibantu melalui pertanyaanpertanyaan $\rightarrow$ Bimbingan dan tenggang rasa.

\section{Langkah-langkah Pembelajaran Matematika Realistik}

Mengacu pada karakteristik pembelajaran matematika realistik di atas, maka langkah-langkah dalam kegiatan inti proses pembelajaran matematika realistik pada penelitian ini adalah :

Langkah 1 : Memahami masalah kontekstual 
Guru memberikan masalah kontekstual dan siswa memahami permasalahan tersebut.

Langkah 2 : Menjelaskan masalah kontekstual

Guru menjelaskan situasi dan kondisi soal dengan memberikan petunjuk/saran seperlunya (terbatas) terhadap bagian-bagian tertentu yang belum dipahami siswa. Penjelasan ini hanya sampai siswa mengerti maksud soal.

Langkah 3 : Menyelesaikan masalah kontekstual

Siswa secara individu menyelesaikan masalah kontekstual dengan cara mereka sendiri. Guru memotivasi siswa untuk menyelesaikan masalah dengan cara mereka dengan memberikan pertanyaan/petunjuk/saran.

Langkah 4 : Membandingkan dan mendiskusikan jawaban

Guru menyediakan waktu dan kesempatan pada siswa untuk membandingkan dan mendiskusikan jawaban dari soal secara berkelompok. Untuk selanjutnya dibandingkan dan didiskusikan pada diskusi kelas.

Langkah 5: Menyimpulkan

Dari diskusi, guru mengarahkan siswa menarik kesimpulan suatu prosedur atau konsep, dengan guru bertindak sebagai pembimbing.

Hobri (2009: 170-172)

Pandangan belajar yang berbasis pada pembelajaran matematika realistik adalah siswa secara aktif mengkonstruksi sendiri pengetahuan matematika. Hal terpenting adalah siswa dapat mengetahui kapan dan dalam konstruk apa mereka menerapkan konsep-konsep matematika itu dalam menyelesaikan suatu persoalan. Sedangkan guru bukan lagi penyampai informasi yang sudah jadi, tetapi sebagai pendamping bagi siswa untuk aktif mengkonstruksi. 
Realistic Mathematics Education : Model Alternatif Pembelajaran Matematika Sekolah

Materi Pelajaran dalam pembelajaran matematika realistik dikembangkan dari situasi kehidupan sehari-hari yaitu dari apa yang telah didengar, dilihat atau dialami oleh siswa. Situasi dan kegiatan dalam kehidupan sehari-hari yang pernah dirasakan atau dijumpai oleh siswa merupakan pengetahuan yang dimilikinya secara informal. Oleh karena itu, dalam memberikan pengalaman belajar kepada siswa hendaknya diawali dari sesuatu yang real/nyata bagi siswa.

\section{Keunggulan dan Kelemahan Pembelajaran Matematika Realistik}

Menurut Suwarsono (dalam Hobri, 2009: 173-174) kelebihankelebihan Realistic Mathematics Education (RME) atau Pembelajaran Matematika Realistik (PMR) adalah sebagai berikut :

1. RME memberikan pengertian yang jelas dan operasional kepada siswa tentang keterkaitan antara matematika dengan kehidupan sehari-hari dan tentang kegunaan matematika pada umumnya kepada manusia.

2. RME memberikan pengertian yang jelas dan operasional kepada siswa bahwa matematika adalah suatu bidang kajian yang dapat dikonstruksi dan dikembangkan sendiri oleh siswa dan oleh setiap orang “biasa” yang lain, tidak hanya oleh mereka yang disebut pakar dalam bidang tersebut.

3. RME memberikan pengertian yang jelas dan operasional kepada siswa bahwa cara penyelesaian suatu soal atau masalah tidak harus tunggal, dan tidak harus sama antara orang satu dengan orang yang lain.

4. RME memberikan pengertian yang jelas dan operasional kepada siswa bahwa dalam mempelajari matematika, proses pembelajaran merupakan suatu yang utama dan untuk mempelajari matematika orang harus menjalani sendiri proses itu dan berusaha untuk menemukan sendiri konsep-konsep dan materi-materi matematika 
yang lain dengan bantuan pihak lain yang sudah tahu (guru). Tanpa kemauan untuk menjalani sendiri proses tersebut, pembelajaran yang bermakna tidak akan terjadi.

5. RME memadukan kelebihan-kelebihan dari berbagai pendekatan pembelajaran lain yang juga dianggap "unggul”.

6. RME bersifat lengkap (menyeluruh), mendetail dan operasional. Proses pembelajaran topik-topik matematika dikerjakan secara menyeluruh, mendetail dan operasional sejak dari pengembangan kurikulum, pengembangan didaktiknya di kelas, yang tidak hanya secara makro tapi juga secara mikro beserta proses evaluasinya.

Selain kelebihan-kelebihan seperti yang diungkapkan di atas, terdapat juga kelemahan-kelemahan Realistic Mathematics Education (RME) yang oleh Suwarsono (dalam Hobri, 2009: 175-176) adalah sebagai berikut:

1. Pemahaman tentang RME dan pengimplementasian RME membutuhkan paradigma, yaitu perubahan pandangan yang sangat mendasar mengenai berbagai hal, misalnya seperti siswa, guru, peranan sosial, peranan kontek, peranan alat peraga, pengertian belajar dan lain-lain. Perubahan paradigma ini mudah diucapkan tetapi tidak mudah untuk dipraktekkan karena paradigma lama sudah begitu kuat dan lama mengakar.

2. Pencarian soal-soal yang kontekstual, yang memenuhi syarat-syarat yang dituntut oleh RME tidak selalu mudah untuk setiap topik matematika yang perlu dipelajari siswa, terlebih karena soal tersebut masing-masing harus bisa diselesaikan dengan berbagai cara.

3. Upaya mendorong siswa agar bisa menemukan cara untuk menyelesaikan tiap soal juga merupakan tantangan tersendiri.

4. Proses pengembangan kemampuan berpikir siswa dengan memulai soal-soal kontekstual, proses matematisasi horizontal dan proses matematisasi vertikal juga bukan merupakan sesuatu yang sederhana karena proses dan mekanisme berpikir siswa harus diikuti dengan 
Realistic Mathematics Education : Model Alternatif Pembelajaran Matematika Sekolah

cermat agar guru bisa membantu siswa dalam menemukan kembali terhadap konsep-konsep matematika tertentu.

5. Pemilihan alat peraga harus cermat agar alat peraga yang dipilih bisa membantu proses berpikir siswa sesuai dengan tuntutan RME.

6. Penilaian (assesment) dalam RME lebih rumit daripada dalam pembelajaran konvensional.

7. Kepadatan materi pembelajaran dalam kurikulum perlu dikurangi secara substansial, agar proses pembelajaran siswa bisa berlangsung sesuai dengan prinsip-prinsip RME.

\section{Teori Belajar yang Melandasi Pembelajaran Matematika Realistik}

a) Teori Belajar Ausubel

Ausubel mengelompokkan belajar menjadi dua dimensi (dalam Makmur Sugeng, 2004: 25). Dimensi pertama, berhubungan dengan cara informasi atau materi pelajaran disajikan kepada siswa, melalui penerimaan atau penemuan. Dimensi kedua, menyangkut cara bagaimana siswa dapat mengaitkan informasi tersebut pada struktur kognitif yang telah ada.

Pada tingkat pertama, belajar penerimaan (reception learning) menyangkut materi dalam bentuk final, sedangkan belajar penemuan (discovery learning) yang mengharuskan siswa untuk menemukan sendiri sebagian atau seluruh materi yang dipelajari.

Pada tingkat kedua, siswa menghubungkan atau mengaitkan informasi tersebut pada konsep-konsep dalam struktur kognitifnya, dalam hal ini "belajar bermakna (meaningful learning)". Tetapi siswa mungkin saja tidak mengaitkan informasi tersebut pada konsep-konsep yang ada dalam struktur kognitifnya; siswa hanya terbatas menghafal informasi baru tersebut; dalam hal ini terjadi “ belajar hapalan (rote learning)”.

Pada pembelajaran matematika realistik, karakteristik pertama yaitu menggunakan masalah konstektual yang berfungsi sebagai motivasi awal atau "starting point" dalam pembelajaran, guru meminta kepada siswa 
untuk mengguakan strategi atau cara mereka sendiri dalam memecahkan masalah. Untuk keperluan tersebut siswa harus mampu menghubungkan pengetahuan yang dimiliki dengan permasalahan yang dihadapi. Bila pengetahuan/ konsep yang dimiliki siswa belum dapat digunakan dalam memecahkan masalah, maka guru perlu membimbing siswa (bersifat terbatas) dalam menemukan konsep tersebut. Dengan demikian siswa akan mampu menyelesaikan masalah konstektual yang diajukan kepadanya apabila ia memiliki cukup pengetahuan yang terkait dengan masalah tersebut.

Dari uraian ini, maka yang melandasi diberikan dari teori belajar bermakna Ausubel untuk pembelajaran matematika realistik adalah kemampuan siswa dalam menghubungkan pengetahuan yang ada dengan masalah konstektual yang sedang dibahas. Kemampuan ini akan sangat membantu dalam menyelasaikan masalah yang dihadapi.

b) Teori Piaget

Teori belajar kognitif yang terkenal adalah teori Piaget. Teori Piaget sering disebut sebagai genetic epistemology (epistemologi genetik) karena teori ini berusaha melacak perkembangan kemampuan intelektual (Hergenhahn dan Olson, 2008: 313). Menurut Piaget (dalam Makmur Sugeng, 2004: 26), perkembangan intelektual didasarkan pada dua fungsi, yaitu organisasi dan adaptasi.

Organisasi memberikan kemampuan untuk mensistematikkan atau mengorganisasi proses-proses fisik atau proses-proses psikologi menjadi sistem-sistem yang teratur dan berhubungan atau struktur-struktur. Adaptasi merupakan organisasi yang cenderung untuk menyesuaikan diri atau beradaptasi dengan lingkungannya. Adaptasi terhadap lingungan dilakukan melalui dua proses yaitu asimilasi dan akomodasi. Dalam proses asimilasi, orang menggunakan struktur atau kemampuan yang sudah ada untuk menanggapi masalah yang dihadapi dalam lingkungannya. Dalam proses akomodasi, orang memerlukan modifikasi struktur mental yang sudah ada 
Realistic Mathematics Education : Model Alternatif Pembelajaran Matematika Sekolah

untuk menanggapi respon terhadap masalah yang dihadapi dalam lingkungannya.

Adaptasi merupakan suatu keseimbangan antara asimilasi dan akomodasi. Dalam proses asimilasi seseorang menggunakan struktur atau kemampuan yang sudah ada dalam pikirannya untuk mengadakan respon terhadap tantangan lingkungan. Dalam proses akomodasi seseorang memerlukan modifikasi semata yang ada dalam mengadakan respon terhadap tantangan. Jika dalam proses asimilasi, seseorang tidak dapat mengadakan adaptasi maka akan terjadi proses ketidakseimbangan (disequilibrium), yaitu ketidaksesuaian atau ketidakcocokan antara pemahaman saat ini dengan pengalaman baru, yang mengakibatkan akomodasi. Perkembangan intelektual merupakan proses terus menerus tentang keadaan ketidakseimbangan dan keadaan seimbang (disequilibriumequlibrium). Tetapi bila kembali terjadi keseimbangan, maka individu itu berada pada tingkat intelektual yang lebih tinggi dari pada sebelumnya (Makmur Sugeng, 2004: 27).

Teori Piaget tentang perkembangan intelektual ini menggambarkan tentang konstruktivisme, sehingga psikolog pertama yang menggunakan filsafat konstruktivisme dalam proses belajar mengajar sehingga muncullah teori belajar konstruktivisme. Pandangan tersebut menggambarkan bahwa perkembangan intelektual adalah suatu proses dimana anak secara aktif membangun pemahamannya dari hasil pengalaman dan interaksi dengan lingkungannya. Anak secara aktif membangun pengetahuannya dengan terus menerus melakukan akomodasi dan asimilasi terhadap informasiinformasi baru yang diterimanya.

Implikasi dari teori Piaget dalam pembelajaran (dalam Makmur Sugeng, 2004: 27) sebagai berikut:

1. Memusatkan perhatian pada proses berfikir anak, bukan sekedar pada hasilnya. 
2. Menekankan pada pentingnya peran siswa berinisiatif sendiri dan keterlibatannya secara aktif dalam pembelajaran. Dalam pembelajaran di kelas pengetahuan jadi tidak mendapat penekanan melainkan anak didorong menemukan sendiri melalui interaksi lingkungannya.

3. Memaklumi adanya perbedaan individual dalam hal kemajuan perkembangan. Sehingga guru harus melakukan upaya khusus untuk mengatur kegiatan kelas dalam bentuk individu-individu atau kelompok-kelompok kecil.

Berdasarkan teori Piaget, RME dalam kegiatan pembelajaran memfokuskan pada proses berfikir siswa, bukan sekedar pada hasil. Selain itu dalam pembelajaran ini mengutamakan peran siswa berinisiatif untuk menemukan jawaban dari soal konstektual yang diberikan guru dengan caranya sendiri dan siswa didorong untuk terlibat aktif dalam kegiatan pembelajaran untuk mengonstruksi atau menemukan konsep.

c) Teori Vygotsky

Selain Piaget, tokoh teori belajar kognitif lainnya adalah Vygotsky. Vyotsky (dalam Makmur Sugeng, 2004: 28) menekankan pada hakekat sosiokultural pembelajaran, yaitu siswa belajar melalui interaksi dengan orang dewasa dan teman sebaya. Lebih lanjut Vygotsky yakin bahwa fungsi mental yang lebih tinggi umumnya muncul dalam percakapan atau kerjasama antara individu (interaksi dengan orang dewasa dan teman sebaya) sebelum fungsi mental yang lebih tinggi itu terserap ke dalam individu tersebut.

Ide penting lain yang dapat diambil dari teori Vygotsky adalah scaffolding yaitu pemberian sejumlah besar bantuan kepada seseorang siswa selama tahap awal pembelajaran dan kemudian siswa tersebut mengambil alih tanggung jawab yang semakin besar segera setelah ia dapat melakukannya. Bantuan tersebut dapat berupa petunjuk, peringtan atau dorongan yang memungkinkan siswa tumbuh sendiri. 
Realistic Mathematics Education : Model Alternatif Pembelajaran Matematika Sekolah

Implikasi teori Vygotsky dalam pembelajaran sebagai berikut:

1. Dikehendaki tatanan kelas berbentuk pembelajaran koopratif antar siswa, sehingga siswa dapat berinteraksi disekitar tugas-tugas yang sulit dan saling memunculkan Zone of Proximal Development mereka, yaitu tingkat perkembangan sedikit di atas tingkat perkembangan seorang siswa saat ini.

2. Pendekatan Vygotsky dalam pembelajaran menekankan scaffolding yang berarti pemberian sejumlah besar bantuan kepada siswa selama tahap-tahap awal pembelajaran dan kemudian siswa mengambil alih tanggung jawab yang semakin besar segera setelah ia dapat melakukannya.

Teori Vygotsky ini sejalan dengan salah satu karakteristik dari pembelajaran matematika realistik yang menekankan perlunya interaksi (interactivity) yang terus menerus antara siswa yang satu dengan siswa yang lain, juga antar siswa dengan pembimbing (guru) dan siswa dengan perangkat pembelajaran sehingga setiap siswa mendapatkan manfaat positif dari interaksi tersebut. Hal ini terlihat di dalam kelompok (masing-masing kelompok 6-7 siswa) yang dirancang pada proses pembelajaran. Selain itu dalam pembelajaran matematika realistik bantuan yang diberikan guru hanya sebatas pada pertanyaan-pertanyaan siswa di awal pemecahan masalah konstektual yang diberikan pembimbing (guru), dengan memberikan petunjuk atau saran sampai siswa mengerti dengan maksud soal.

d) Teori Bruner

Menurut Bruner (dalam Makmur Sugeng, 2004: 30) belajar matematika ialah belajar tentang konsep-konsep dan struktur-struktur matematika yang terdapat dalam materi yang dipelajari serta mencari hubunan-hubungan antara konsep-konsep dan struktur-struktur matematika 
itu. Pemahaman terhadap konsep dan struktur suatu materi menjadikan materi itu dipahami secara lebih komprehensif. Selain dari itu pengetahuan siswa lebih mudah diingat dan bertahan lama materi bila yang dipelajari mempunyai pola yang terstruktur. Dengan memahami konsep dan struktur akan mempermudah terjadinya transfer.

Bruner (dalam Makmur Sugeng, 2004: 30) menggabarkan tiga tahap perkembangan siswa yaitu:

1. Enactive, pada tahap ini siswa di dalam belajar menggunakan manipulasi objek-objek secara langsung.

2. Iconic, tahap ini menyatakan bahwa kegiatan siswa mulai menyangkut mental yang merupakan gambaran dari objek-objek.

3. Simbolic, pada tahap ini siswa memnipuasi symbol-simbol secara langsung dan tidak lagi ada kaitannya dengan objek-objek.

Berdasarkan teori Bruner, RME cocok dalam kegiatan pembelajaran karena di awal pembelajaran sangat dimungkinkan siswa memanipulasi objek-objek yang ada kaitannya dengan masalah kontekstual yang diberikan guu secara langsung. Kemudian pada proses matematisasi vertikal siswa memanipulasi simbol-simbol.

Dari uraian di atas jelaslah bahwa teori belajar Ausubel, Piaget, Vygotsky dan Bruner sama-sama menekankan pada keaktifan siswa untuk mengkonstruksi atau membangun sendiri pengetahuan mereka sampai menemukan konsep, menekankan proses belajar terletak pada siswa sedangkan guru berfungsi sebagai pembimbing atau fasilitator, dan belajar ditekankan pada proses dan bukan hanya produk. Hal ini sejalan dengan prinsip karakteristik dari Realistic Mathematics Education (RME) atau Pembelajaran Matematika Realistik (PMR).

\section{Matematika Sekolah}

Matematika yang diajarkan dijenjang persekolahan yaitu Sekolah dasar, Sekolah Lanjutan Pertama,dan Sekolah Menengah Umum disebut matematika sekolah. Terdapat perbedaan antara matematika dan 
Realistic Mathematics Education : Model Alternatif Pembelajaran Matematika Sekolah

matematika sekolah, yang terletak pada; penyajian yang disesuaikan dengan perkembangan intelektual siswa, pola pikir pada proses pembelajaran yang menggunakan pola pikir induktif, keterbatasan semesta yang disesuaikan dengan tingkat usia siswa, dan tingkat keabstrakan yang dimulai dari tahapan konkret dalam membantu penalaran siswa menuju tahap abstrak.

Soedjadi (2000: 193) mengemukakan bahwa matematika sekolah adalah unsur-unsur dan bagian-bagian dari matematika yang dipilih berorientasi kepada:

1. Makna kependidikan yaitu untuk mengembangkan kemampuan dan kepribadian siswa.

2. Tuntutan perkembangan nyata dari lingkungan hidup senantiasa berkembang seiring dengan kemajuan ilmu dan teknologi.

Matematika sekolah memiliki acuan dalam pelaksanaan proses pembelajaran yang berlandaskan kurikulum. Pembelajaran matematika sekolah memerlukan optimalisasi model pembelajaran yang lebih menekankan keterlibatan aktif siswa dalam mengkonstruk pengetahuan.

\section{PENUTUP}

Pembelajaran Matematika Realistik (PMR) merupakan operasionalisasi dari suatu pendekatan pendidikan matematika yang telah dikembangkan di Belanda oleh Institut Freudenthal dengan nama Realistic Mathematics Education (RME). Pembelajaran matematika realistik pada dasarnya adalah pemanfaatan realitas dan lingkungan yang dipahami siswa untuk memperlancar proses pembelajaran matematika, sehingga mencapai tujuan pendidikan matematika secara lebih baik dari pada yang lalu. Yang dimaksud dengan realita yaitu hal-hal yang nyata atau kongret yang dapat diamati atau dipahami siswa lewat membayangkan pada lingkungan 
tempat siswa berada, baik lingkungan sekolah, keluarga maupun masyarakat yang identik disebut sebagai kehidupan sehari-hari.

Pembelajaran matematika realistik menggunakan masalah kontekstual (contextual problems) sebagai titik tolak dalam belajar matematika. Perlu dicermati bahwa suatu hal yang bersifat kontekstual dalam lingkungan siswa di suatu daerah, belum tentu bersifat konteks bagi siswa di daerah lain. Pembelajaran pada matematika sekolah dengan PMR harus disesuaikan dengan keadaan daerah tempat siswa berada.

Masalah dalam pembelajaran matematika sekolah merupakan suatu upaya untuk siswa menghadapi dunia nyatanya. Siswa perlu dipersiapkan secara aktif untuk menyelesaikan masalah-masalah yang terjadi. Masalah yang disajikan oleh guru ke siswa adalah masalah kontekstual yakni masalah yang memang semestinya dapat diselesaikan siswa sesuai dengan pengalaman siswa dalam kehidupan sehari-hari yang akan dihadapinya di lingkungan sehingga konstruksi pengetahuan menjadi lebih optimal. Oleh karena itu, pembelajaran matematika di sekolah diharapkan dapat mengaktivasi pengetahuan siswa yang terkonsep melalui pembelajaran matematika realistik.

\section{Daftar Pustaka}

Hergenhahn dan Matthew H. Olson. 2008. Theories of learning (Teori Belajar). Jakarta: Kencana Prenada media Group.

Hobri. 2009. Model-Model Pembelajaran Inovatif. Jember: Center for Society Studies.

Joko Bekti Haryono. 2005. Pembelajaran Matematika Realistik Pokok Bahasan Relasi dan Pemetaan pada Siswa Kelas II SMP Negeri Di Sukoharjo. Tesis. Surakarta: Pasca Sarjana UNS

Makmur Sugeng. 2004. Pengaruh Pembelajaran Realistik Terhadap Prestasi Belajar Matemalika Unit Geometri Ditinjau dari Respon Siswa Terhadap Proses Pembelajaran pada Siswa Kelas III IPA SMU Negeri Kota Surakarta. Tesis. Surakarta: Pasca Sarjana UNS 
Realistic Mathematics Education : Model Alternatif Pembelajaran Matematika Sekolah

Marpaung. 1998. "Pendekatan Sosio Kultural dalam Pembelajaran Matematika dan Sains ", et al. Pendidikan yang Humanistis, Yogyakarta: Kanisius.

R. Soedjadi. 2000. Kiat Pendidikan Matematika di Indonesia. Jakarta: Direktorat Dikti Departemen Pendidikan Nasional.

Sutarto Hadi. 2007. Keberaksaraan Matematika. Majalah PMRI Vol. V, Januari 2007. Bandung: IP-PMRI.

Zainurie. 2007. Pembelajaran Matematika Realistik (RME). www. geocities.com nurilma rme html. diakses 15 April 2014.

\section{Seri Ningsih}

IAIN Antasari, Banjarmasin

E-mail: seri.ningsih02@gmail.com 
Seri Ningsih 